received: 15 January, 2016 accepted: 30 October, 2016

\title{
MOTIVES FOR PARTICIPATION IN THE SHARING ECONOMY - EVIDENCE FROM LITHUANIA
} pages: $7-17$

\author{
VIRGINIJA GRYBAITÉ, JELENA STANKEVIČIENĖ
}

\begin{abstract}
A B S T R A C T
Information and communication technologies enable the emergence of a new phenomenon called the "sharing economy". An increasing number of articles in the media as well as debates about the positive and negative aspects of the sharing economy show a growing interest in the subject. The paper aims to review the different approaches to the definition of the sharing economy and to present the authors' views on the concept. The reviewed literature reveals the main drivers for participating in the sharing economy. A survey was conducted to learn more about the motives of Lithuanian people participating in this concept. The survey reveals the following leading factors of using the sharing economy platforms: an easy way to make extra money; supporting individuals and/or small/independent companies; meeting new people and having an interesting experience/doing something most people haven't tried yet. The survey also reveals that most of the respondents prefer to own things rather than share them. Despite the widespread popularity of the sharing economy platforms in the world, this phenomenon is in its infancy in Lithuania.
\end{abstract}

KEY WORDS

sharing economy, collaborative economy, collaborative consumption, peer-to-peer

DOI: 10.1515/emj-2016-0028
Corresponding author:

Virginija Grybaitè

Vilnius Gediminas Technical University, Faculty of Business Management, Department of Economics and Management of Enterprises, Lithuania

e-mail: virginija.grybaite@vgtu.It

Jelena Stankevičienè

Vilnius Gediminas Technical University, Faculty of Business Management, Department of Finance Engineering, Lithuania

e-mail: jelena.stankeviciene@vgtu.It

\section{INTRODUCTION}

The last few years have seen a keen interest in a new phenomenon - the sharing economy. A new paradigm of consumption and shared use instead of ownership of resources is emerging. As Leadbeater (2009) wrote: "in the economy of things, you are identified by what you own - your land, house, car. In the economy of ideas that the web is creating, you are what you share... The biggest change the web will bring is in allowing us to share with one another in new ways". Leadbeater (2007) states "if the 20th century was the age of industrial work, mass production for mass consumption, then mass participation will be one of the defining features of the century to come". An increasing number of articles in the press and on the Internet as well as discussions in social networks 
show a growing interest in the sharing economy. Questions have been raised about the overall importance of the sharing economy and future directions. There are also discussions about the main factors determining the rise of the sharing economy, its impact on economic growth and the ways, in which it affects the labour market. However, it can be observed that there are different approaches to the sharing economy. Proponents and opponents have investigated positive and negative aspects (Schor, 2010, 2014; Childs, 2013; Sundararajan, 2014; Zervas et al., 2016; Gaskins, 2010; Yglesias, 2013). Supporters of the sharing economy highlight the benefits that it provides: the possibility to earn extra money, meet people, find new friends, and save costs. Proponents of the sharing economy assert that it provides new opportunities for individuals by putting their inactive assets to work, thus earning additional income. For example, an empty room, a car or some tools they do not need to use every day can be shared as underutilized assets and earn money. This allows people to use the assets only when needed and pay for their temporary use rather than ownership. This changes consumer behaviour. It can, therefore, be said that a new approach to the ownership of things is emerging. Sharing can be described as an alternative to private ownership. Items can be used when they are needed, not requiring their ownership. Sceptics, on the other hand, emphasize potentially negative aspects of the sharing economy and the new challenges it brings, e.g. De Grave (2014) states that "people in the sharing economy are nothing but an extreme precariat". Orsi (2013) refers to the legal problems of the sharing economy. Malhotra \& Van Alstyne (2014), Koopman et al. (2015), Katz (2015) examine the impact of the sharing economy on traditional businesses and regulation issues. The traditional service providers, e.g. hotels, taxi companies and banks complain that the rules of the game are unfair. It is argued that while normal services are regulated (e.g. licenses, employment regulations, hygiene, security, etc.), the sharing economy platform companies are not. It should be noted, that the largest sectors of the sharing economy are accommodation, transport, household, professional, technical, and financial services.

Despite numerous discussions about positive or negative aspects of this new phenomenon, there is no commonly accepted definition of the sharing economy. New terms such as the collaborative consumption, the collaborative economy, the sharing economy, the peer economy, and the gig economy are emerging in the literature, and in many cases, these new terms describe the same phenomenon. However, it should be emphasized that some authors use these terms interchangeably, while others differentiate between them by offering separate definitions for each. Regardless of the fact, there is no consensus on the definition of the sharing economy. Differences in the understanding of this rapidly growing phenomenon are also observed. Moreover, there have also been discussions whether the meaning of sharing has been consistent with the phenomenon that we refer to as the "sharing economy". In general, the literature of the sharing economy could be divided into two main groups: one concerning legal aspects of the sharing economy, and the other studying its impact on traditional businesses. It should also be noted that some authors examine whether the meaning of the word "sharing" is the same in the business model described as the sharing economy.

The main purpose of this article is to learn how the sharing economy is characterized by different authors. Therefore, the main literature on the sharing economy will be reviewed. Moreover, the paper seeks to investigate the motives for and arguments against the participation in the sharing economy. If people are willing to participate in the sharing economy, what assets are they willing to share? Furthermore, the authors have raised the question whether the motives to participate in the sharing economy differ among countries. Surveys have been conducted in various countries, but not in Lithuania. The authors raise the question whether people in Lithuania are aware of the sharing economy and what motives they have to participate in it.

\section{DEFINITION ISSUES OF THE SHARING ECONOMY}

The Oxford English Dictionary (OED) provides the following definition of the sharing economy: "an economic system in which assets or services are shared between private individuals, either for free or for a fee, typically by means of the Internet". Zervas et al. (2016) define the sharing economy just as "multisided technology platforms" (Table 1). In many cases, the terms sharing economy, collaborative consumption, and connected consumption are used interchangeably. Besides, we can discover that the concept of the sharing and collaborative economy has been used synonymously (e.g. it illustrates the event, which 
Tab. 1. Definition of the sharing economy

\begin{tabular}{|c|c|}
\hline AUTHOR (SOURCE) & DEFINITION \\
\hline Belk, R. (2007) & $\begin{array}{l}\text { Sharing is an alternative to the private ownership that is emphasized in both } \\
\text { marketplace exchange and gift giving }\end{array}$ \\
\hline Botsman, R. (2015) & $\begin{array}{l}\text { An economic system based on sharing underused assets or services, for free or for } \\
\text { a fee, directly from individuals }\end{array}$ \\
\hline De Grave, A. (2014) & $\begin{array}{l}\text { The sharing economy is just one part of the collaborative economy, as is distributed } \\
\text { production, P2P (peer-to-peer) finance and the open source and knowledge } \\
\text { movements }\end{array}$ \\
\hline Dervojeda, K. et al. (2013) & Accessibility-based business models for peer-to-peer markets \\
\hline Hamari, J. et al. (2015) & $\begin{array}{l}\text { An umbrella concept that encompasses several ICT developments and technologies, } \\
\text { among others CC, which endorses sharing the consumption of goods and services } \\
\text { through online platforms }\end{array}$ \\
\hline Matofska, B. (2016) & $\begin{array}{l}\text { A socio-economic ecosystem built around the sharing of human, physical and } \\
\text { intellectual resources }\end{array}$ \\
\hline Olson, M. J. \& Kemp, S. J. (2015) & $\begin{array}{l}\text { A sharing economy is a market whereby: } \\
\text { 1) Users are individuals, businesses, or machines; } \\
\text { 2) There is excess supply of an asset or skillset and sharing creates economic benefit } \\
\text { for both the sharer and the user; } \\
\text { 3) The Internet provides means for communication and coordination of the sharing }\end{array}$ \\
\hline Parsons, A. (2014) & $\begin{array}{l}\text { The sharing economy leverages information technology to empower individuals } \\
\text { or organisations to distribute, share and re-use excess capacity in goods and services }\end{array}$ \\
\hline PricewaterhouseCoopers (2015) & $\begin{array}{l}\text { Sharing economies allow individuals and groups to make money from underused } \\
\text { assets }\end{array}$ \\
\hline Schor, J. B., \& Fitzmaurice, C. J. (2015) & $\begin{array}{l}\text { The wide and varied range of old, revamped and new practices whose central } \\
\text { characteristics are the ability to save or make money, provide a novel consumer } \\
\text { experience, reduce ecological and carbon footprints, and strengthen social ties }\end{array}$ \\
\hline Stephany, A. (2015) & $\begin{array}{l}\text { The sharing economy is the value in taking underutilized assets and making them } \\
\text { accessible online to a community, leading to a reduced need for ownership of those } \\
\text { assets }\end{array}$ \\
\hline Wosskow, D. (2014) & Online platforms that help people share access to assets, resources, time and skills \\
\hline Zervas, G. et al. 2016 & Multi-sided technology platforms \\
\hline www.investopedia.com & $\begin{array}{l}\text { A sharing economy is an economic model in which individuals are able to borrow } \\
\text { or rent assets owned by someone else }\end{array}$ \\
\hline www.oxforddictionaries.com/words/about & $\begin{array}{l}\text { An economic system in which assets or services are shared between private } \\
\text { individuals, either for free or for a fee, typically by means of the Internet }\end{array}$ \\
\hline
\end{tabular}

has been held in Brussels on February 2016. The event's title "The sharing/collaborative economy" (http:// bruegel.org/events/the-sharingcollaborative-economy/). However, De Grave (2014) states that the concepts of the collaborative economy and the sharing economy are different. De Grave (2014) emphasizes that the sharing economy is part of the collaborative economy, it "is distributed production, peer-to-peer finance and the open source and knowledge movements". Still, the terms sharing economy and collaborative consumption are used interchangeably by De Grave as well (2014). Table 1 shows the definition of the sharing economy suggested by various authors.
Erving (2014) has raised the question of how profit-making companies and individuals who share their assets for free, could fit into the category of the sharing economy. Furthermore, in Matthew Yglesias' (2013) view, the sharing economy is an inappropriate term to describe business models, such as short-term car or bike rentals. According to the author, when a firm owns a number of cars and offers them to its customers as short-term rentals, this kind of activity cannot be attributed to the sharing economy. That is not car sharing but business. Transactions in the sharing economy do not encompass sharing in the traditional understanding of the word "sharing". Belk (2014) sustains that approach and argues that some new activities, using such new terms as the sharing 
economy, in essence, are not sharing at all and are better characterized as "pseudo-sharing - commodity exchanges wrapped in a vocabulary of sharing". According to Belk (2007) "sharing is an alternative to private ownership that is emphasized in both marketplace exchange and gift giving. In sharing, two or more people may enjoy the benefits (or costs) that flow from possessing a thing. Rather than distinguishing what is mine and yours, sharing defines something as ours".

Furthermore, Belk (2014) distinguished four types of pseudo-sharing:

- long-term renting and leasing;

- short-term rental;

- online sites "sharing" your data;

- online-facilitated barter economies.

According to Belk (2014), the true forms of sharing are ephemeral intentional online sharing, onlinefacilitated offline sharing, peer-to-peer online sharing and, online facilitated sharing.

Botsman (2013) argues that the terms collaborative consumption, collaborative economy, sharing economy, and peer economy have different meanings, but they also have common essential ideas that explain the overlap. Hamari et al. (2013) state that the concept of the sharing economy is derived from the collaborative consumption concept. Botsman and Roo (2010) attempt to define the concept of the collaborative consumption by describing it as "traditional sharing, bartering, lending, trading, renting, gifting and swapping, redefined through technology and peer communities". In the author's view, the collaborative consumption can be divided into three systems: product service systems, redistribution markets, and collaborative lifestyles. Product service systems are characterized by allowing members to pay for the benefit of using a product without the need of owning it. Redistribution markets are redistributing things from someone who does not need them to someone who does. eBay was founded more than twenty years ago, in 1995 and can be described as the first widely known marketplace for the redistribution of things. eBay is "dedicated to bringing together buyers and sellers in an honest and open marketplace" (https://www.ebayinc.com/). This sentence describes the essence of the sharing economy platforms: linking people who have goods, which are no longer needed or wanted, with people who need them. And the third system of collaborative lifestyles can be described as sharing and exchange of intangible assets such as time, skills, and experience. Schor (2014) takes a similar approach arguing that the shar- ing economy activities fall into four broad categories: recirculation of goods, increased utilization of durable assets, exchange of services, and sharing of productive assets. Schor and Fitzmaurice (2015) expanded the categories described above by adding one more, i.e. building social connections.

Bostman (2013) defines the collaborative consumption as part of the collaborative economy, which she describes as "an economy built on distributed networks of connected individuals and communities versus centralized institutions, transforming how we can produce, consume, finance, and learn". The collaborative economy involves collaborative finance, collaborative consumption, collaborative education, and collaborative production (Fig. 1).

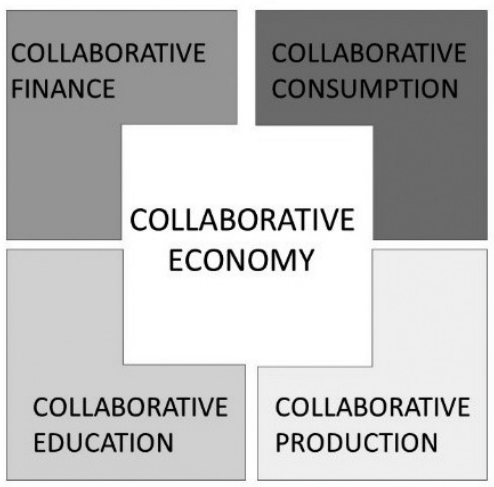

Fig. 1. Collaborative economy components

Source: authors' elaboration based on (Botsman, 2015).

It should be noted that the collaborative economy is transforming the way people produce, consume, finance, and learn. The collaborative economy is transforming businesses and society by leveraging technology efficiently by matching supply and demand in a trusted environment. Bostman (2013) describes the sharing economy as an economic model based on sharing underutilized assets for monetary or non-monetary benefits. Besides, Bostman (2013) characterizes peer economy as person-to-person marketplaces that facilitate the sharing and direct trade of products and services built on peer trust. As shown in Figure 2, the collaborative consumption is a part of the collaborative economy. The collaborative consumption involves product service systems, redistribution markets, and collaborative lifestyles.

As noted above, the concept of the sharing economy is derived from the collaborative consumption concept. Accordingly, Bostman (2015) says that the sharing economy embraces "sharing underused assets or services". Bostman (2015) defines the sharing 


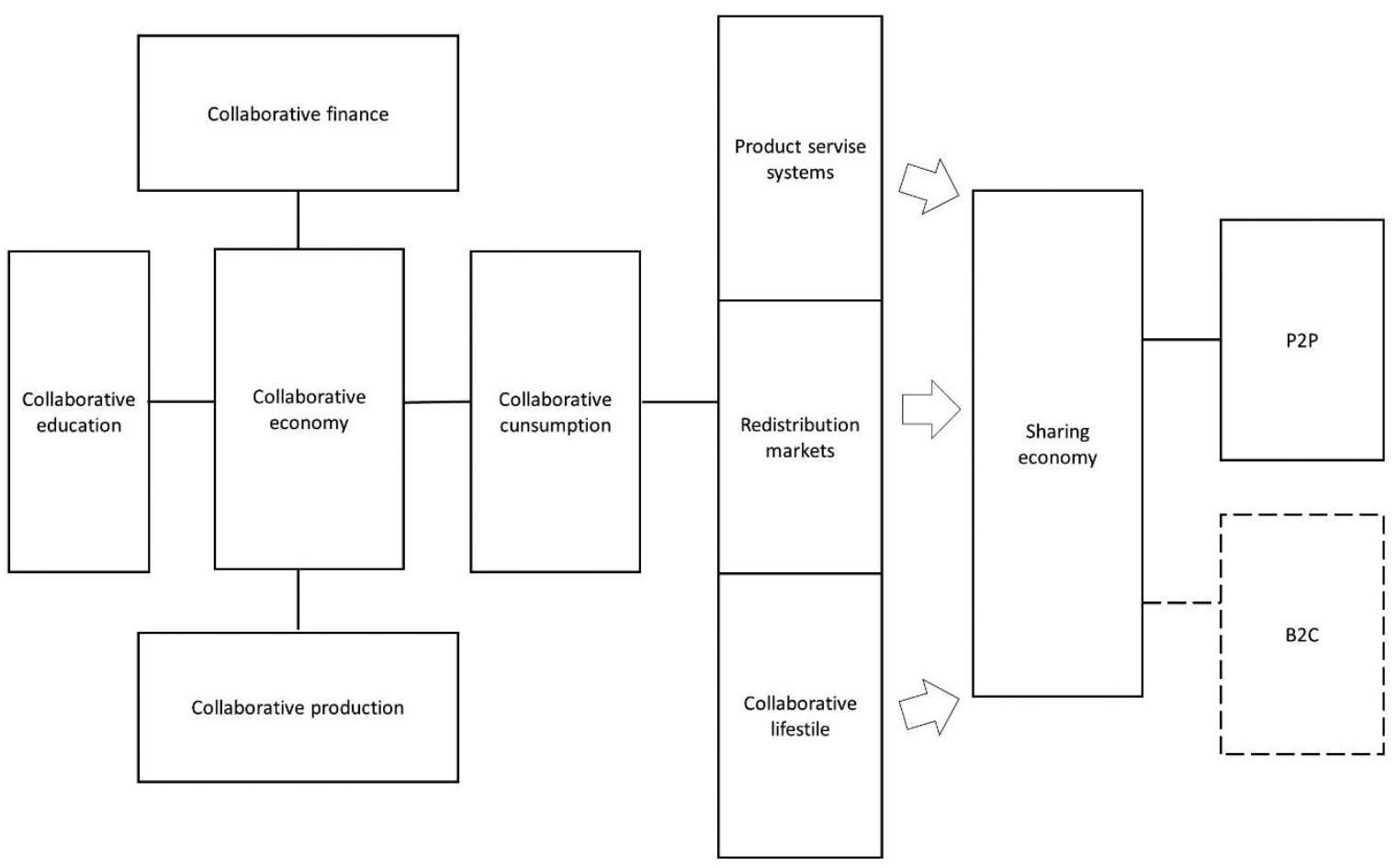

Fig. 2. Sharing economy in the context of the collaborative economy

Source: author's elaboration based on (Bostman, 2013).

economy narrowly, only as trading between individuals. De Grave (2014), Dervojeda et al. (2013), Wosskow (2014) and others take a similar approach and focus only on the peer-to-peer business model.

The authors of this paper propose a broader concept of the sharing economy, including not only private individuals but businesses as well. Furthermore, the authors propose peer-to-peer, business-topeer, and business-to-business models. It is noted that new technologies, such as the Internet are the main drivers for the expansion of the sharing economy. New technologies have enabled the emergence of new multi-sided platforms, where people or organisations can share assets, skills, time, etc. The authors would like to underline, that the term "sharing" should not be understood in an altruistic way as helping others or charity. It is a matter of convenience, a fast and simple way to serve consumers who need products or services. They "share" those products or services via digital platforms.

In authors' view, the sharing economy could be defined as multi-sided digital platforms that create an open market for services and products and act as an intermediary between users and service providers. Members of the sharing economy can be individuals as well as businesses.

\section{EMERGENCE OF THE SHARING ECONOMY}

The sharing of unused goods for free or for money is not a revolutionary innovation. Today, the Internet and mobile technologies provide new forms and opportunities. It should be pointed out, that the most important factor that influenced the development and expansion of the sharing economy are digital technologies since they changed the traditional market behaviour, which was not previously possible. Even though the Internet is more than 20 years old, there has been a recent rapid development of the new technologies that enable changes in human behaviour and allow new opportunities. The rise of social media networks, the development of smart devices, and innovative technologies have had an enormous impact on business (Kaplan \& Haenlein, 2010; Delina \& Tkáč, 2015). Digital technologies are advancing at a very fast rate. They are not only transforming the way people interact but are also inventing a new way, in which people consume and what they consume (Hosu \& Iancu, 2016; Wang \& Zhang, 2012). As Sundararajan (2016) points out, a confluence of digital enablers created by wireless broadband, mass market smartphones, digitalized social networks, i.e. the development of digital technologies, is one of the 
main factors that influences the emergence and growth of the sharing economy. Furthermore, Sundararajan (2016) defines three fundamental forces that distinguished digital technologies from other GPT (general purpose technologies). These forces are: rendering things as information and presenting information digitally; the growth of hardware power, the storage and miniaturization of digital devices; and increased programmability and modularity of devices. Digital technologies enable new types of sharing services. It should be stated, that

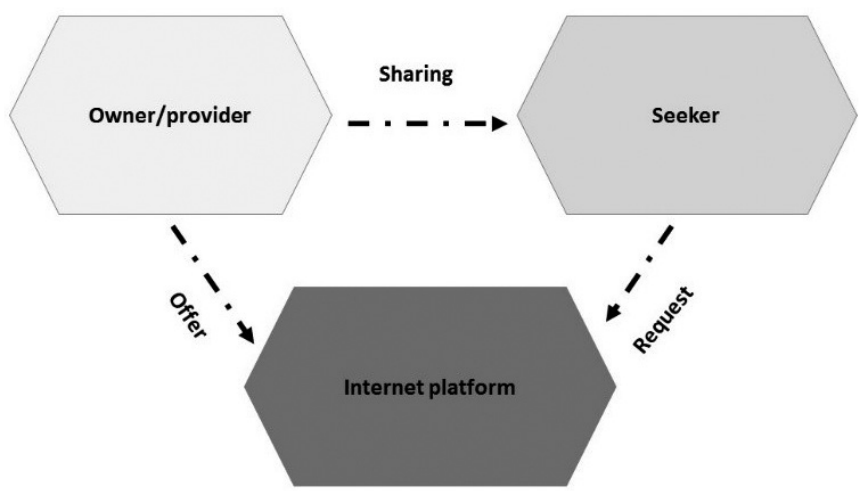

Fig. 3. Model of the sharing economy model Internet platforms and smartphone applications connect people who need services with those who can provide them (Schor, 2014; Smith, 2016). The sharing economy platforms differ from singlesided platforms where a single seller offers his/her products to buyers. The sharing economy platforms are peer-to-peer decentralized platforms where two members interact directly with each other without the need of a third-party intervention. Sundararajan (2014) describes the platforms as a person-to-person marketplace, which facilitates the exchange of goods and services between peers. Individuals or small businesses supply goods and services to these marketplaces and individuals (called consumers) buy, rent and consume.

On the other hand, the Internet and technological progress are not the only factors leading to the emergence and popularity of the sharing economy. According to Parson (2014), the economic downturn and other aspects, such as government austerity and environmental concerns, influenced the new paradigm of the shared use of resources. Botsman and Roo (2010) take a different approach and assert that the sharing economy no only responds to the economic downturn or consequence of the global financial crisis, but that it is a growing movement with millions of members who participate in the movement and receive benefits from it.

The benefits of the sharing economy are that it provides a greater range of services, gives users more options to choose from, and can offer a higher quality of service at a better price. New types of services based on digital platforms bring together users and service providers, satisfying user expectations to the best possible extent and, furthermore, contribute to the promotion of innovation and the increase in transparency. Information technology allows the sharing of goods for a short period, quickly, conveniently, and at an attractive price. It fundamentally changes consumer habits since it provides the opportunity for people to consider and evaluate the pros and cons of purchasing the items. The sharing economy model contains three parts: sellers (or owners of assets), buyers (or seekers for goods and services) and developers of digital platforms (Fig. 3). Collaborative or sharing Internet platforms create an open market for services and products.

\section{BENEFITS OF THE SHARING ECONOMY}

The proponents of the sharing economy indicate the following benefits for the consumers: adjusting to the needs of individuals rather than reacting to changes in demand; offering unique experiences that commercial providers cannot ensure; and lower prices compared to commercial providers (Olson \& Kemp, 2015). Sundararajan (2014) believes "that peer-to-peer business enabled by digital platforms will constitute a significant segment of the economy in the coming years. It is likely that this transition will have a positive impact on economic growth and welfare by stimulating new consumption, by raising productivity, and by catalyzing individual innovation and entrepreneurship".

It should be noted, that the sharing economy creates new networks within societies. It creates trust and builds community, people feel connected to neighbours or co-workers. The success of the sharing economy is based on people's trust in one another. So the reputation and the ability of market participants to sell their services is especially important. If the user is not satisfied with service provider's work, he gets a low rating on the Internet, and other potential customers may decide not to use services from that service provider. 
The sharing economy is believed to be advantageous to the environment because it makes greater use of existing resources and the potential energy savings that would result from car sharing and bike sharing. Schor (2010) talks about environmental crisis that humanity faces and suggests that it can have a radical change in people's values, how they think about consumer goods and how they live. It is believed that social innovations and new technologies can simultaneously enhance peoples' lives and protect our planet. Furthermore, Schor (2010) believes that economics based on sharing could help rebuild the social ties that have been lost through hyper-consumer culture.

It can be argued that benefits of the sharing economy correspond with the dimensions of sustainable development: economic, social and environmental (Table 2).

Tab. 2. Benefits of the sharing economy

\begin{tabular}{|c|c|c|}
\hline ECONOMIC BENEFITS & $\begin{array}{c}\text { ENVIRON- } \\
\text { MENTAL }\end{array}$ & SOCIAL BENEFITS \\
\hline - raising productivity & - resource & - make \\
- catalysing individual & efficiency & meaningful \\
innovation and & potential & connections \\
entrepreneurship & energy & - re-emergence of \\
- cost savings & savings & community \\
& & - social inclusion \\
\hline
\end{tabular}

It should be mentioned, that the sharing economy could contribute to the achievement of sustainable development goals. Therefore, considerations should be given to the incorporation of new indicators to the current set of indicators that measure sustainable development goals.

\section{INTENTION TO PARTICIPATE IN THE SHARING ECONOMY}

The sharing economy depends on people's intention to share. Therefore, Nielsen (2014) conducted a global survey of how people in different parts of the world are willing to participate in sharing communities (\% of online consumers willing to participate in the sharing economy). The results of the survey are shown in Figure 4.

The Nielsen survey also reveals the kind of products people are willing to share. People around the world are most willing to share or rent electronic devices for a fee (28\%), $26 \%$ of global respondents are keen to share intellectual property, $23 \%$ - power tools, $22 \%$ - bicycle, 22\% - clothing, and 22\% household items (Nielsen, 2014).

Another survey conducted by Hamari et al. (2015) investigated the main drivers for participating in the collaborative consumption. Hamari et al. (2015) gathered information from people registered on the Collaborative Consumptions site. The findings reveal that sustainability, enjoyment of the activity and economic gains were the main factors encouraging people to participate in the collaborative consumption.

In 2014, Havas Worldwide partnered with Market Probe International and surveyed 10574 people, aged 16 and older from 29 countries. $46 \%$ of respondents agree they would rather share things than own them. The survey reveals that the most appealing aspects of the sharing economy are: saving money $(32 \%)$, feeling active and useful (13\%), reducing

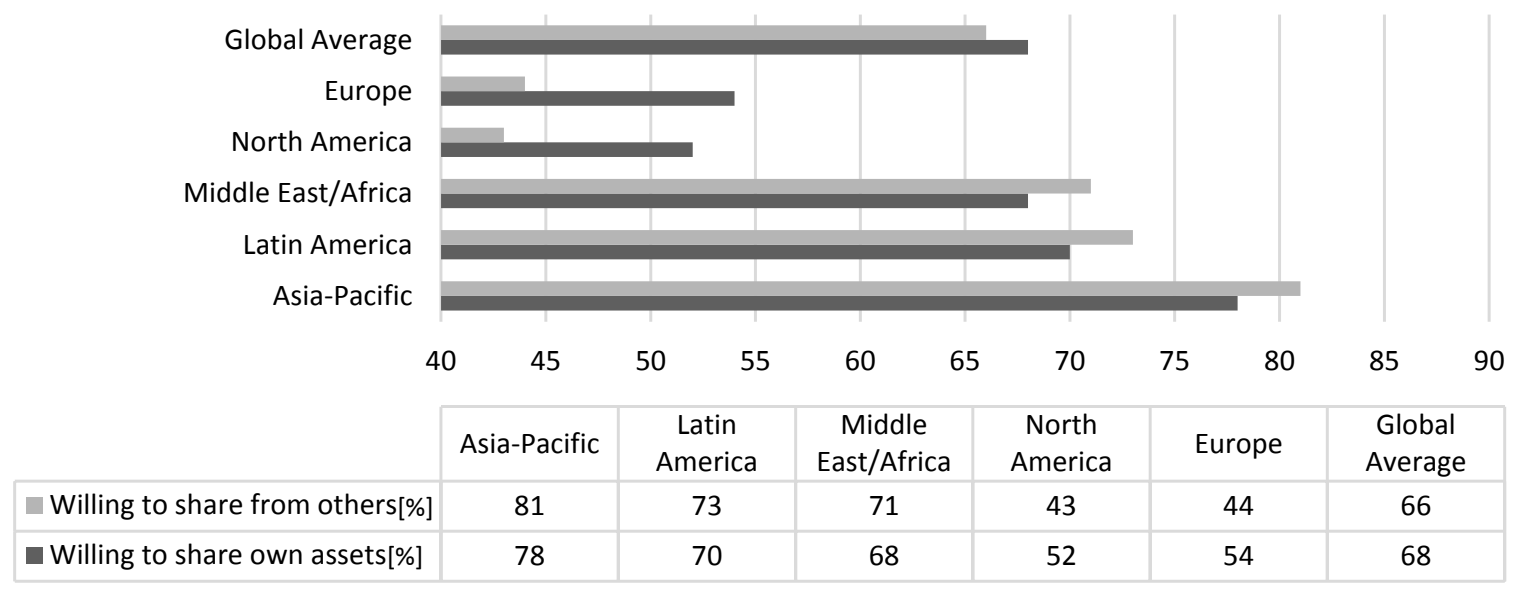

Fig. 4. Participation in the sharing economy

Source: authors' elaboration based on (Nielsen, 2014). 


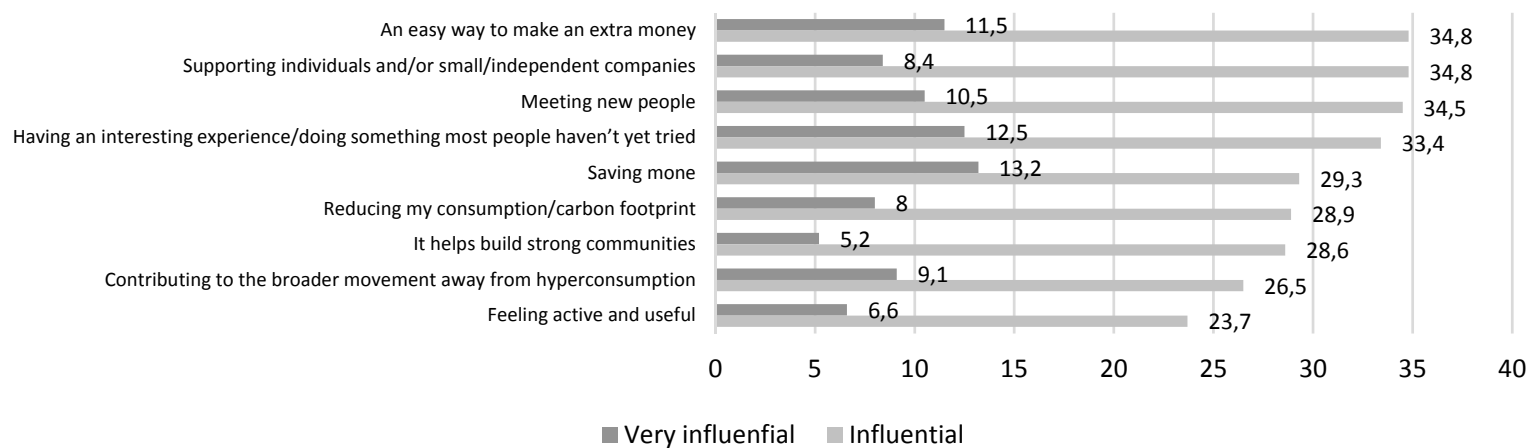

Fig. 5. Factors that influence participation in the sharing economy [\%]

consumption/carbon footprint (13\%), contributing to the broader movement by staying away from hyperconsumption (10\%), supporting individuals and/or small/independent companies (9\%), having an interesting experience/doing something most people have not tried (8\%), and meeting new people (6\%).

The authors of this paper conducted a survey in Lithuania. To learn more about the motives of Lithuanian people to participate in the sharing economy, a survey of 287 persons aged 18-25 years was conducted. The survey revealed that $32 \%$ of respondents have not heard about the sharing economy and even though $68 \%$ of respondents were aware of the sharing economy, only $33.8 \%$ of them have used the sharing economy services. $52.6 \%$ of respondents did not know if they would participate in the sharing economy in the future, and only $20,6 \%$ answered, that their participation will increase. Only $15.7 \%$ of respondents agree they would rather share things than own them and $36.6 \%$ of respondents disagreed with the statement.

The respondents were asked to select factors that influence their participation in the sharing economy. The leading factors for using the sharing economy platforms were an easy way to make extra money (34.8\%), supporting individuals and/or small/independent companies $(34.8 \%)$, meeting new people (34.5\%), and having an interesting experience/doing something most people haven't yet tried (33.4\%), (Fig. 5).

Respondents were asked if they would consider sharing things or paying someone to borrow their things in the next 12 months. Figure 6 shows what respondents consider sharing in the next 12 months, and Figure 7 shows what respondents consider paying someone to borrow their things in the next 12 months.

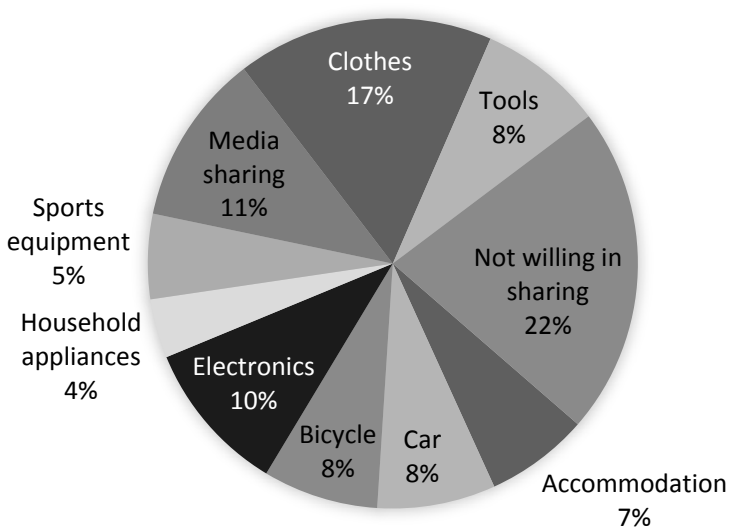

Fig. 6. Consider sharing things for money in the next 12 months

As shown in Figures 5 and 6, 16\% of respondents are not willing to borrow from others, and $22 \%$ are not willing to share their goods with others. Despite the widespread popularity of the sharing economy platforms in the world, this phenomenon is in its infancy in Lithuania. The author's survey produced a unique response in the sharing of items. While most literature indicate that people are willing to share

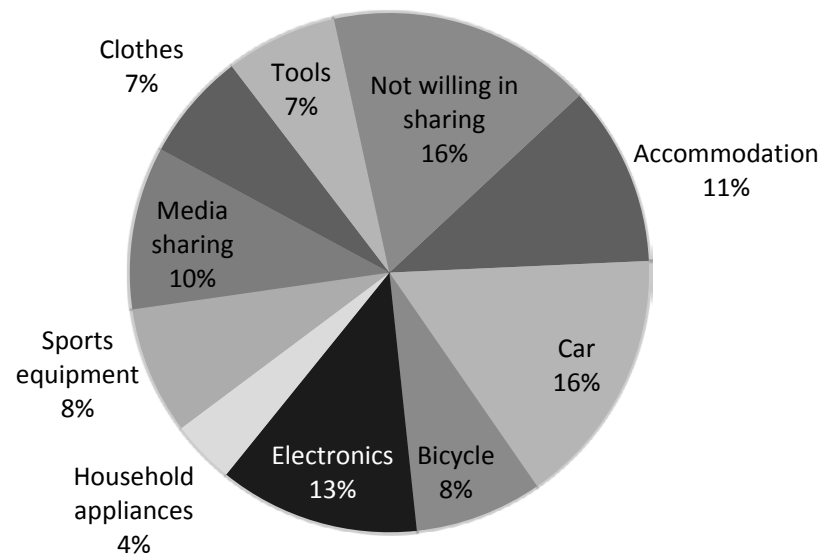

Fig. 7. Consider paying someone to borrow their things in the next 12 months 
electronics, bikes, and similar items, in Lithuania, the most common item was clothing.

The survey reveals that only $33.8 \%$ of respondents in Lithuania have used the sharing economy services, and $52.6 \%$ of respondents did not know if they would participate in it in the future. As Sundararajan (2016) emphasizes, wireless broadband, mass market smartphones, digitalized social networks are the crucial elements of the sharing economy. If people do not have Internet access or a smartphone, they are not able to participate in the sharing economy through the sharing economy digital platforms. It should be noted, that in terms of the technological development, Lithuania does not lag behind the most developed countries. As shown in Figure 8, in mobile phone subscriptions per 100 inhabitants, Lithuania is ahead of such countries as the USA, Germany, the United Kingdom and France.

As shown in Figure 9, Lithuania does not lag far behind the more developed countries in terms of individuals using the Internet. In 2015, Lithuania had $71.38 \%$ of individuals using the Internet, while the USA had $74.55 \%$, France - $84.69 \%$, Germany $-87.59 \%$, and the UK - 92\%. Furthermore, Lithuania is far ahead in the EU in terms of its broadband speed and fibre-to-premises penetration.

In Lithuania as well as other developed countries, the requirements for creating and using digital platforms and participating in the sharing economy are present. However, no legal restrictions exist for the sharing economy companies in Lithuania. Thus, one can say that Lithuania has all the possibilities for creating and using digital platforms. Therefore, one must look elsewhere for the reasons why people are not engaging in the sharing economy. There might be many reasons such non-participation, such as the lack of information about the sharing economy, its benefits, opportunities, etc. One can conclude that it could be very informative and beneficial to conduct a survey on such a subject.

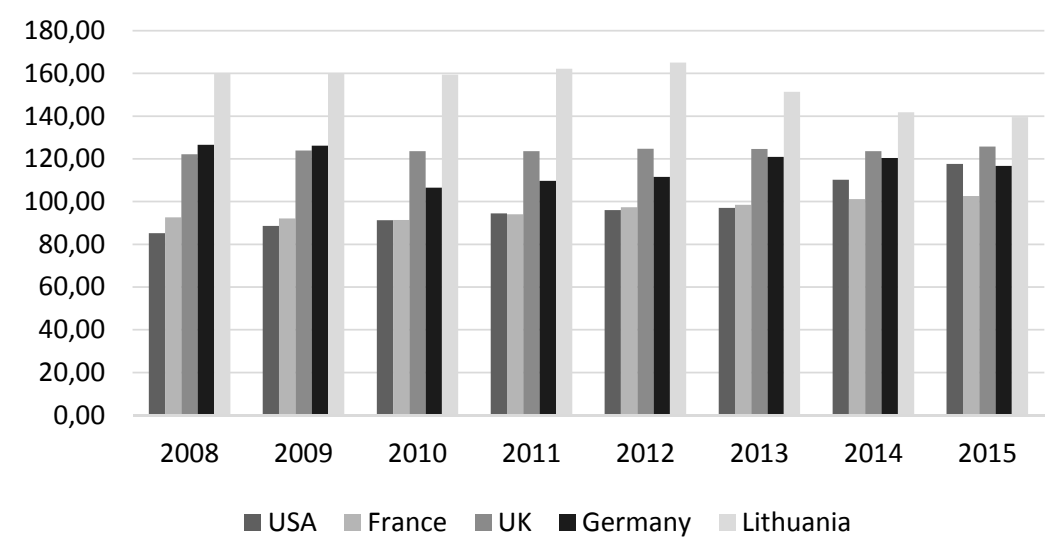

Fig. 8. Mobile-cellular telephone subscriptions per 100 inhabitants Source: (ITU).

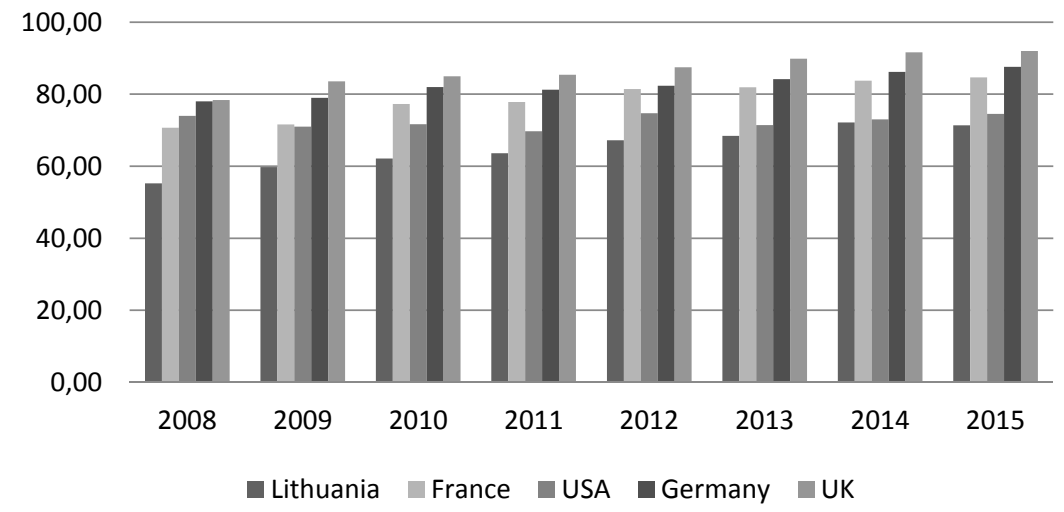

Fig. 9. Percentage of individuals using the Internet

Source: (ITU).

\section{CONCLUSIONS}

The sharing economy is a new phenomenon, and there are still many unanswered questions concerning its impact on traditional businesses and the labour market or its future directions. Consequently, it is important to analyse the sharing economy's impact on employment. What are its opportunities or challenges to the labour market? The sharing economy aspects, such as the impact on GDP should be explored. However, the authors of the article note the lack of statistics concerning the sharing economy. Consequently, further research is necessary to have a meaningful debate about its benefits.

It should be noted that there is no consensus on the definition of the sharing economy. Usually, the sharing economy is defined rather narrowly, highlighting trade 
between individuals. The authors propose a broader concept of the sharing economy and state that the sharing economy could be defined as multi-sided digital platforms that create an open market for services and products and act as an intermediary between users and service providers. Members of the sharing economy could be individuals and businesses.

Surveys available in the literature and that the survey conducted by the authors reveal that the most important factors that influence participation in the sharing economy are economic: saving money and an easy way to make extra money. However, social factors, such as being useful to society and supportive to local communities are noted as well.

Future research should emphasize the contribution of the sharing economy to the sustainable development. The question of how much sharing economy contributes to the sustainable development should be raised.

\section{LITERATURE}

Belk, R. (2007). Why not share rather than own? Annals of the American Academy of Political and Social Science, 611, 126-140.

Bostman, R. (2013). The Sharing Economy Lacks A Shared Definition. Retrieved from http://www.fastcoexist. com/3022028/the-sharing-economy-lacks-a-shareddefinition?partner=rss\&utm_source $=$ feedburner \&utm_medium $=$ feed\&utm_campaign $=$ Feed $\% 3 \mathrm{~A}+\mathrm{f}$ astcoexist $\% 2$ Ffeed+\%28Co.Exist $\% 29 \# 1$

Botsman, R. (2015). Defining The Sharing Economy: What Is Collaborative Consumption - And What Isn't? Retrieved from http://www.fastcoexist.com/3046119/ defining-the-sharing-economy-what-is-collaborative-consumption-and-what-isnt

Botsman, R., \& Rogers, R. (2010). What's Mine is Yours: How Collaborative Consumption is Changing the Way We Live. HarperCollins Business.

Childs, M. (2013). The Power of Sharing: A Call to Action for Environmentalists. Retrieved from http://www.shareable.net/blog/the-power-of-sharing-a-call-toaction-for-environmentalists

Wang, C., \& Zhang, P. (2012). The Evolution of Social Commerce: The People, Management, Technology, and Information Dimensions. Management, Technology, and Information Dimensions, Communications of the Association for Information Systems, 31, 5.

De Grave, A. (2011). The Sharing Economy: Capitalism's Last Stand? Retrieved from http://ourworld.unu. edu/en/the-sharing-economy-capitalisms-last-stand

Delina, R., \& Tkáč, M. (2015). Role of e-business in the perception of ICT impact on revenue growth. Journal of Business Economics and Management, 16(6), 11401153. doi: 10.3846/16111699.2013.797012
Dervojeda, K. et al. (2013). The sharing economy. Accessibility based business models for Peer to Peer markets. European Union.

Erving, E. E. (2014). The Sharing Economy: Exploring the Intersection of Collaborative Consumption and Capitalism, Scripps Senior Theses. Paper 409. Retrieved from http://scholarship.claremont.edu/scripps_theses/409

Gaskins, K. (2010). Shareable/Latitude 42: The New Sharing Economy Study.

Hamari, J., Sjöklint, M., \& Ukkonen, A. (2015). The sharing economy: Why people participate in collaborative consumption. Journal of the Association for Information Science and Technology. doi: 10.1002/asi.23552

Havas Worldwide. (2014). The new consumer and the sharing economy. Havas Report, Volume 18.

Hosu, I., \& Iancu, I. (2016). Digital Entrepreneurship and Global Innovation. Business Science Reference. doi: 10.4018/978-1-5225-0953-0

Kaplan, A. M., \& Haenlein, M. (2010). Users of the world, unite! The challenges and opportunities of Social Media. Business Horizons, 53, 59-68.

Katz, V. (2015). Regulating the Sharing Economy. Berkeley Technology Law Journal, 30(4), 1068-1126.

Koopman, C., Mitchell, M., \& Thierer, A. (2015). The Sharing Economy and Consumer Protection Regulation: The Case for Policy Change. The Journal of Business, Entrepreneurship \& the Law, 8(2), 530-545.

Leadbeater, C. (2007). We Think: why mass creativity is the next big thing. Retrieved from http://charlesleadbeater.net/2010/01/we-think/

Leadbeater, C. (2009). We-Think: Mass Innovation, Not Mass Production. London: Profile Books.

Malhotra, A., \& Van Alstyne, M. (2014). The Dark Side of the Sharing Economy... and How to Lighten It. Communications of the ACM, 57(11), 24-27.

Matofska, B. (2016). What is the Sharing Economy? Retrieved from http://www.thepeoplewhoshare.com/blog/ what-is-the-sharing-economy/

Nielsen (online). (2014). Retrieved from http://www. nielsen.com/us/en/insights/reports/2014/is-sharingthe-new-buying.html

Olson, M. J., \& Kemp, S. J. (2015). Sharing Economy: An In-Depth Look Its Evolution \& Trajectory Across Industries. Piper Jaffray Investment Research: March. Retrieved from http://collaborativeeconomy.com/ wp/wp-content/uploads/2015/04/Sharing-Economy-An-In-Depth-Look-At-Its-Evolution-and-Trajectory-Across-Industries-.pdf

Orsi, J. (2013). The Sharing Economy Just Got Real. Retrieved from http://www.shareable.net/blog/the-sharingeconomy-just-got-real

Parsons, A. (2014). The sharing economy: a short introduction to its political evolution. Retrieved from http:// www.sharing.org/information-centre/articles/sharing-economy-short-introduction-its-politicalevolution\#sthash.M2lqtM1i.dpuf

PricewaterhouseCoopers. (2015). The Sharing economy. Retrieved from https://www.pwc.com/us/en/technology/publications/assets/pwc-consumer-intelligence-series-the-sharing-economy.pdf 
Schor, J. (2014). Debating the Sharing Economy. Retrieved from http://www.greattransition.org/publication/debating-the-sharing-economy

Schor, J., \& Fitzmaurice, C. (2015). Collaborating and connecting: the emergence of the sharing economy. In J. F. Schor (Ed.), Handbook on Research on Sustainable Consumption. Edward Elgar.

Schor, J. B. (2010). Plenitude: The New Economics of True Wealth. MP3 CD.

Smith, A. (2016). Shared, Collaborative and On Demand: The New Digital Economy. Retrieved from http:// www.pewinternet.org/2016/05/19/the-new-digitaleconomy/

Stephany, A. (2015). The Business of Sharing: making it in the New Sharing Economy. Palgrave Macmillan UK.

Sundararajan, A. (2014). Peer-to-Peer Businesses and the Sharing (Collaborative) Economy: Overview, Economic Effects and Regulatory Issues. Retrieved from http:// smallbusiness.house.gov/uploadedfiles/1-15-2014_ revised_sundararajan_testimony.pdf

Sundararajan, A. (2016). The Sharing Economy: The End of Employment and the Rise of Crowd-Based Capitalism. The MIT Press.

Wosskow, D. (2014). Unlocking the sharing economy. An independent review. Retrieved from https://www.gov. uk/government/uploads/system/uploads/attachment_data/file/378291/bis-14-1227-unlocking-thesharing-economy-an-independent-review.pdf

Yglesias, M. (2013). There Is No "Sharing Economy". Retrieved from http://www.slate.com/blogs/moneybox/2013/12/26/myth_of_the_sharing_economy_ there_s_no_such_thing.html

Zervas, G., Proserpio, D., \& Byers, J. W. (2016). The Rise of the Sharing Economy: Estimating the Impact of Airbnb on the Hotel Industry. Retrieved from http://papers. ssrn.com/sol3/papers.cfm?abstract_id=2366898

ITU. Retrieved from http://www.itu.int/en/ITU-D/Statistics/Pages/stat/default.aspx

Belk, R. (2014). Sharing Versus Pseudo-Sharing in Web 2.0. Anthropologist, 18(1), 7-23. 